\title{
Alokasi Situs-Situs Arkeologi Di Kawasan DAS Way Sekampung
}

Rr. Triwurjani

Keywords: watershed, distribution, archaeological data, spatial

\section{How to Cite:}

Triwurjani, R. Alokasi Situs-Situs Arkeologi Di Kawasan DAS Way Sekampung. Berkala Arkeologi, 15(3), 177-179 https://doi.org/10.30883/jba.v15i3.691

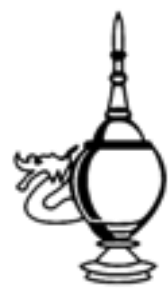

\section{Berkala Arkeologi}

https://berkalaarkeologi.kemdikbud.go.id/

Volume 15 No. 3, 1995, 177-179

DOI: $10.30883 /$ jba.v15i3.691 


\title{
ALOKASI SITUS-SITUS ARKEOLOGI \\ DI KAWASAN DAS WAY SEKAMPUNG
}

\author{
Rr. Triwurjani \\ (Pusat Penelitian Arkeologi Nasional)
}

\section{Permasalahan.}

Lampung merupakan salah satu daerah di Samatera Selatan yang mempunyai tinggalan arkeologis yang cukup potensial dan besar, setelah daerah Palembang. Penelitian arkeologis di daerah Lampung telah berhasil menampakkan berbagai ragam tinggalan arkeologis, termasuk juga dalam periodesasinya. Beberapa tinggalan arkeologis tersebut antara lain: Kompleks Megalitik, Benteng Tanah, parasati-parasati baik dari masa Sriwijaya maupun Kesultanan Banten, arca batu, keramik asing, keramik lokal dan artefak-artefak lainnya.

Penelitian-penelitian arkeologis terdahulu telah membuktikan beberapa temuan arkeologis banyak tersebar di wilayah Lampung meliputi daerah Lampung Tengah, Lampung Selatan dan Lampung Utara. Penggalian-penggalian tersebut setelah dipetakan secara akurat temyata mengikuti pola keletakan sumber air, seperti sungai, ataupun mata air. Peninggalan-peninggalan ini tidak terbatas pada tinggalan arkeologis bersifat religius tetapi juga tingalan arkeologis yang berhubungan dengan kehidupan sosial manusia masa lalu

Secara garis besar tinggalan-tinggalan tersebut dapat dipetakan tersebar di sepanjang Way Sekampung yang dapat dibagi atas daerah hulu, tengah dan hilir. Tinggalan-tinggalan tersebut tidak hanya tersebar di sepanjang Way Sekampung tetapi juga di Daerah Aliran Sungai (DAS) Sekampung

Bila diurut dari hulu hingga hilir, sungai Sekampung memanjang dari Lampung Selatan hingga Lampung Tengah. Bebarapa tinggalan arkeologis yang terdapat didaerah hulu antara lain: Kompleks Megalitik Batu Bedil. Batu Gajah, dan juga Benteng Tanah. Sedangkan di bagian tengah terdapat situs Bukit Wungkal (Silitonga), Kampung Tua, Bentang Pejambon, situs Megalitik Sidomukti. Sedangkan di daerah hilir terdapat kompieks Megalitik Pogung Raharjo, Benteng Sari, Benteng Perigi, Benteng Gedik, Benteng $\mathrm{Ci}$ cilik, makam kuno dari masa Islam, Prasasti Bungkuk dari batu dan temuan-temuan lepas lainnya seperti keramik asing (Cina) dan keramik lokal, alat batu dan artefak lainnya.

Temuan-temuan ini tidak mustahil akan terus bermunculan seiring dengan kerapnya penelitian arkeologi di DAS Sekampung tersebut. Dengan beragamnya tinggalan arkeologis baik dari masa Prasejarah, masa Klasik, Islam atau- pun Kolonial di sepanjang Way Sekampung membuktikan bahwa Way Sekampung sangat berperan besar bagi kehidupan manusia masa lalu.

Bagaimana dan faktor-faktor apa yang berperan ataupun yang berpengaruh atas pemilihan Situs-situs pada dataran di sepanjang sungai Sekampung, sangat menarik untuk dikaji. Pendekatan kawasan sebagai implementasi dari survey arkeologis di sepanjang DAS Sekampung secara horizontal, sangat diharapkan dapat menjawab beberapa permasalahan yang timbul. Kawasan (region, off-site) sebagai basic categones of archeological evidence (Renfrew \& Bahn, 1991; Kusumohartono, 1994) sangat penting dikaji bagi kepentingan studi perubahan kebudayaan daiam studi arkeologi (Kusumahartono,1994). Pengajian kawasan dalam hal ini akan mencoba melihat relasi antara artefak, lingkungan alam penemuannya dan manuai pendukungnya.

\section{Pembahasan.}

Sungai Sekampung secara garis besar berada pada dua garis lintang yakni, $104^{\circ} 30^{\prime}$. $105^{\circ}$ $50^{\prime}$ BT dan $5^{\circ} 5^{\prime}-5^{\circ} 37^{\prime}$ LS, dengan ketinggian 1272 $\mathrm{m}$ dpl di bagian hulu, tercantum pda peta topo. grafi lembar 1010 kota Agung dan lembar 1110 Tanjung Karang dengan skala $1: 250.000$

Sungai Sekampung mengalir berkelok-kelok dan telah banyak mengalami erosi-samping dan proses pelebaran lembah secara geologis studi (tingkatan pertumbuhan) DAS Sekampung dan sekitarnya digolongkan pada Stadia Dewasa Tua dengan ciri perbukitan yang membulat dengan lereng yang mulai melandai.

Sungai Sekampung mempunyai hulu jauh di wilayah Lampung Selatan yaitu merupakan gabungan dari Sungai Sekampung Balak dan Sungai Sekampung Tenong. Sungai Sekampung Balak berhulu di Gunung Tangkit Begelung (1272 M) dan Gunung Tangkit Ulu Sekampung (1107 M). Sedangkan Sungai Sekampung Tenong berhulu di Gunung Tangkit Pisang (1091 m). Stadia Dewasa Tua pada sungai Sekampung ditandai dengan Lapangan gradient sungai sedang, aliran sungai bermeander, tidak lagi dijumpai air terjun ataupun danau sepanjang aliran sungai, dan lembahnya lebar. Pengamatan atas tebing sungai menunjukkan bahwa sungai Sekampung telah mengalami peremajaan (rejuvination) ataupun perpindahan sungai secara alami. Hal ini dibuktikan dengan adanya lapisan gravel (kerikil) pada 
beberapa tempat antara lain di Situs Bukit Wungkal (Silitonga), Situs Pejambon, Rejomulyo dan daerah Bumi Agung.

Dilihat dari kualitas air, maka sungai Sekampung termasuk sungai normal yang alirannya konstan dari waktu ke waktu. Pada musim hujan volume airnya banyak dan pada musim kemarau volume airnya sedikit. Sedangkan anak-anak sungai Sekampung pada musim kemarau airnya kering. Anak-anak sungai Sekampung tersebut antara lain: Sungai Putaran, Sungai Keramat, Sungai Kurupan, Sungai Gadingrejo, Sungai Tubalunik, Sungai Batu Keting, Sungai Kenali.

Adapun satuan batuan yang menyusun DAS Sekampung dan sekitarnya terdiri dari ber-bagai batuan sedimen, batuan beku, batuan me-tamorf dan aluvial yang merupakan hasil pela-pukan dari ketiga jenis batuan tersebut. Batuan penyusun tersebut adalah Tufa, batu pasir, batu gamping, Breksi Vulkanik, Andesit, Basal, Diorit, Granit, Skiss \& Aluvial.

Batuan Tufa tersingkap di daerah hulu, dan situs-situs yang termasuk di wilayah tersebut antara lain: Situs Batu Bedil, Situs Pejambon, dan Kampung Tua. Batuan Batu pasir tersingkap di daerah hilir yakni Pogung Raharjo dan sekitamya, termasuk Situs Kemiling. Batu gamping tersingkap di sebagian daerah hulu, di Kampung Negeri Katon, sedangkan Batuan Boeksi Vulkanik tersingkap id daerah Batu Bedil dan sekitarnya. Batuan Jasper dan Batu Rijang (Chert) ditemukan berupa bongkahan baik sebagai singkapan maupun bolder-boulder yang terdapat di sungai llahan, dan hampir sepanjang Way Sekampung. Tidak heran apabila artefak alat batu seperti Kapak Batu, Beliung banyak ditemukan bersama-sama temuan-temuan lain di sepanjang Way Sekampung. Batuan Andesit tersingkap hampir di sepanjang aliran Sungai Sekampung

Di Situs Batu Bedil tidak kurang dari 35 buah menhir, ditambah dengan batu lumpang dan meja batu, sebagian besar menhir-menhir tersebut terbuat dari batu basal dan andesit. Ada beberapa (sedikit) menhir yang terbuat daru batuan breksi vulkanik. Batuan- batuan jenis tersebut di atas memang banyak tersingkap di daerah ini (Situs Batu Bedil). Dan daerah ini dekat dengan daerah perbukitan dan menhir-menhir tersebut menghadap ke arah Gunung Tanggamus, di sebelah Utaranya sebuah prasasti yang terdapat di salah satu menhir di kompleks ini disebut juga prasasti Batu Bedil. Terdiri dari satu tegakan batu monolith dari jenis tufa. Adanya tulisan pada menhir tersebut kemungkinan memang sengaja dipahatkan pada batu yang memang sudah tersedia, akan tetapi bagaimana konteks yang sebenamya belum diketahui dengan pasti. Prasasti
Batu Bedil diperkirakan berasal dari masa Sriwijaya abad 9-10 $M$, bertuliskan Jawa kuno dan berbahasa Sanskerta. Berukuran tinggi $175 \mathrm{~cm}$ dan tebal $45 \mathrm{~cm}$.

Di sebelah Timur $\pm 3 \mathrm{~km}$ dari kompleks Batu Bedil terdapat kompleks megalitik yang disebut dengan Batu Gajah. Jenis batuan di kompleks ini sama dengan jenis batuan pada kompleks megalitik Batu Bedil.

Adanya temuan Benteng-benteng di sebagian daerah hilir Sekampung (Lampung Tengah) menunjukkan adanya suatu pemukiman kuno. Hal ini dibuktikan dengan temuan artefak lepas (keramik asing, lokal, dll.), makam-makam kuno ataupun menhir-menhirt dalam benteng tersebut. Keadaan ini menunjukkan bahwa ada suatu pemukiman kuno yang cukup lama di DAS Sekampung. Pola pemukiman ini dapat dikenali iewat sebaran bentang dari hulu (Pejambon) mengarah ke hilir di daerah Pugung Raharjo.

Bila diamati lebih jauh ternyata makin ke arah hilir makin banyak dijumpai benteng-benteng tanah (Negarasaka dan Bentengsari) sedangkan peninggalan megalitik baik yang merupakan kompleks ataupun temuan yang terkonsentrasi tersebar di sepanjang DAS Sekampung. seperti kompleks megalitik Batu Bedil di daerah hulu dan kompleks megalitik Pugung Raharjo di daerah hilir. Apalagi temuan artefak lepas lainnya keramik Cina misalnya dari masa Dynasti Tang (10-11M), Sung (12-13 M), Yuan (13-14 M), Vietnam (15-16 M), Ming (17 M), Ching (18 M) dan Eropah (19-20 M) banyak ditemukan di sepanjang DAS Sekampung. Beberapa aktivitas manusia masa lalu dapat diidentifikasi melalui konteks temuannya, antara lain aktivitas keagamaan, penguburan, perdagangan, bercocok tanam, pernbuatan gerabah, pemukiman, perlindungan, pertahanan dan pemerintahan.

Melihat temuan-temuan yang ada diketahui bahwa Sungai Sekampung sudah digunakan oleh manusia jauh sebelum abad-abad masehi yakni sejak masa prasejarah. Bagaimana menggambarkan proses budaya yang terjadi di DAS Sekampung bukanlah hal yang mudah. Pene-litian geomorfologis menunjukkan bahwa pada umumnya situs-situs yang terletak di sepanjang DAS Sekampung terletak pada meander sungai yang tinggi.

\section{Penutup.}

Pada dasarnya setiap bentuk lahan memiliki karakteristik tertentu tentang topografi/relief, material penyusun dan proses sehingaa satuan bentuk lahan sering dijadikan dasar pendekatan untuk studi unsur-unsur sumberdaya lahan yang lain dan sering digunakan sebagai dasar 
pemilihan Jahan untuk tujuan tertentu. (Sutikno, 1944-20)

Pandangan Binford (1983) bahwa kebudayaan dan lingkungan alam adalah faktor yang bertanggung jawab terhapda proses perubahan kebudayaan, sangat sesuai diterapkan pada alokasi Situs-situs di DAS Sekampung.

Alokasi Situs-situs arkeologi di daerah Lampung yang mengarah pada sepanjang Sungai Sekampung agaknya telah dipertimbangkan masak-masak oleh pelaku/pendukungnya sebagai proses adaptasi manusia terhadap lingku-ngan dimana dia akan tinggal ataupun sebagai serangkaian gagasan yang dimiliki dalam pendistribusian situs-situs dalam suatu kawasan yang luas. Hal ini telah dibuktikan dengan alokasi Situs Batu Bedil di daerah Lampung Selatan dimana daerah tersebut merupaka tempat batuan Basal, Andesit dan Vulkanik tersingkap (Triwurjani, Fadhlan 1994).

Secara garis besar umumnya Situs-situs di sepanjang Sungai Sekampung sebagian besar terletak pada meander-meander sungai yang tinggi yang sebenarnya daerah ini sangat labil. Secara berkala pada daerah labil ini dapat terjadi petahan-patahan sungai dan dapat menyebabkan terjadinya banjir yang cukup besar sehingga membahayakan bagi manusia yang berdiam di atasnya, seperti halnya pada alokasi Situs bukit Silitonga di Lampung Tengah yang terletak persis di puncak meander sungai. Namun demikian dataran tinggi inilah yang lebih disukai manusia sebagai tempat untuk berinteraksi ataupun beraktivitas dengan alam lingkungannya. Hal ini merupakan suatu kewajaran bahwa secara naluriah manusia membutuhkan suatu tempat berlindung yang aman dari gangguan alam ataupun lainnya. Keadaan ini diperkuat lagi dengan kepercayaan yang melatarinya yaitu bahwa tempat-tempat yang tinggi dan dekat dengan sumber air adalah merupakan tempat yang suci. Dengan demikian bagaimanapun labilnya suatu daerah asalkan memenuhi segala persyaratan pada tingkat tertentu yang dibutuhkan manusia pada satu waktu, tetap akan manjadi pilihan dengan serangkaian hubungan yang ada. Tentu saja dalam hal ini teknologi pada tingkat tertentu telah mereka kuasai dan apabila daerah-daerah terpilih tersebut sudah tidak layak lagi untuk ditempati maka merekapun mencari tempat lain yang lebih layak untuk mereka tinggal dan beraktivitas.

\section{KEPUSTAKAAN}

Bambang Budi Utomo,1983.Penelitian PendahuIuan Situs Arkeologi di daerah Tepi Sungai
Batanghari. PIA III Puslit Arkenas. Depdikbud. Jakarta.

Binford,Lewis.R. 1992. Teori dan Metode Arkeologi Jurnal Arkeologi Indonesia 1 Jakarta: IAAI

Bugie,Kusumohartono,1994. Proses perubahan Kebudayaan dan Kajian Kawasan dalam Arkeologi. EHPA Palembang 10-16 Okt.

1995. Manajemen Sumberdaya Budaya Pendekatan Strategis dan Taktis. Seminar Nasional Metodologi Riset Arkeologi Depok 23-24 Januari 1995. FS UI

Butzer,Karl.W 1982.Archeology as Human Ecology: Methode and Theory for a Contextual approach. Cambridge University Press

F.Lanerry, Kent.V,1992. Sejarah Budaya vs Proses Budaya: Debat Klasik dalam Arkeologi Amerika Jurnal Indonesia no:1 Jakarta |AAI

I Wayan Ardika, 1995. Beberapa pendekatan Dalam Arkeologi Pemukiman, Seminar Nasio. nal Metodologi Riset Arkeologi FS-UI

Hodder, lan, 1991, Reading The Past Current Approaches to Interpretaion in Archaeology. Cambridge University Press

Parsudi Suparlan,ed.1984, Manusia, Kebudayaan dan Lingkungan CV Rajawali Jakarta diterbitkan untuk konsorsium antar Bidang DEPDIKBUD.

Subroto Ph,1983, Studi tentang Pola Pemukiman Arkeologi, Kemungkinan-kemungkinan Penerapannya di Indonesdia PIA III Ciloto:|AA|

Sutikno,1991, Analisis Geomorfologi Program Pendidikan Pelatihan IFSA, Puslit Arkenas DEPDIKBUD Jakarta.

Sutikno, Aris Poniman, Maulana Ibrahim, 1992 Tinjauan Geomorfologi-Geografis Situs Muara Jambi Dan Sekitarnya, Seminar Sejarah Malayu Kuno, Jambi, 7-8 Desember, Kerjasama PEMDA Tk I Prop. Jambi dengan Kanwil DEPDIKBUD Prop. Jambi

Triwurjani,Rr \& Fadhlan,1994, Survei Daerah Aliran Sungai Sekampung Propinsi Lampung. Laporan Penelitian Bidang Arkeometri Puslit Arkenas'(Tidak Terbit).

Tim Peneliti Arkeologi Islam, 1992/1992, Peneli-tian Arkeologi Benteng-benteng Tanah di Sekitar DAS Way Sekampung. Laporan Penelitian Puslit Arkenas (Tidak Terbit). 